\title{
Phylogenetic analysis of the genus Pediococcus, including Pediococcus claussenii sp. nov., a novel lactic acid bacterium isolated from beer
}

\author{
${ }^{1}$ Department of \\ Microbiology and \\ Immunology, University of \\ Saskatchewan, \\ 107 Wiggins Road, \\ Saskatoon, Saskatchewan, \\ Canada S7N 5E5 \\ 2 Brewing Research and \\ Development, Coors \\ Brewing Company, BC 600, \\ Golden, CO 80401-1295, \\ USA \\ 3 Plant Biotechnology \\ Institute, National \\ Research Council, \\ 110 Gymnasium Place, \\ Saskatoon, Saskatchewan, \\ Canada S7N OW9
}

\author{
C. Melissa Dobson, ${ }^{1}$ Harry Deneer, ${ }^{1}$ Sun Lee, ${ }^{2}$ Sean Hemmingsen, ${ }^{3}$ \\ Sarah Glaze ${ }^{1}$ and Barry Ziola ${ }^{1}$
}

Author for correspondence: Barry Ziola. Tel: +1 306966 4330. Fax: +1 3069664311. e-mail: ziola@sask.usask.ca

\begin{abstract}
Pediococci are found in foods and on plants and as beer-spoilage agents. The goal of the present study was to use the DNA sequences of the first three variable regions of the 16S rRNA gene, the 16S-23S rRNA internally transcribed spacer region sequence and approximately a third of the $60 \mathrm{kDa}$ heat-shock protein gene to elucidate phylogenetic groupings within the genus Pediococcus. Phylogenetic trees were created with sequence data from 31 Pediococcus and three Lactobacillus isolates. Complete 16S rRNA gene sequences from selected Pediococcus isolates were also examined. The results were interpreted in relation to the currently accepted Pediococcus species. We found that, where previously done, speciation of many Pediococcus isolates is inaccurate. Also, one grouping of seven isolates did not include any currently recognized Pediococcus species type isolate. Our phylogenetic analyses support the conclusion that these seven isolates, all of brewing spoilage origin, belong to a novel species, for which the name Pediococcus claussenii sp. nov. is

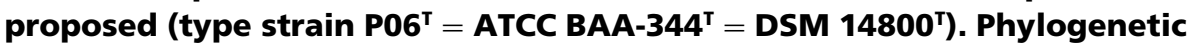
analysis has therefore helped to resolve problems surrounding species identification of Pediococcus isolates.
\end{abstract}

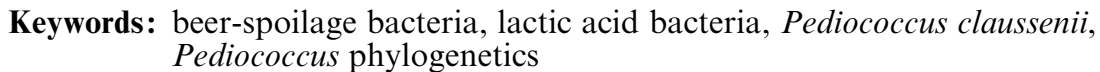

\section{INTRODUCTION}

Pediococci are lactic acid bacteria found on plants and in many fermented foods (Garvie, 1986). Pediococci have been added as nutritional enhancers of animal feeds and, more recently, have been used in polymer research for production of biodegradable packaging materials. In addition to beneficial aspects, when present in beer, pediococci produce diacetyl, causing a quality problem for brewers. Pediococcus speciation

Published online ahead of print on 27 May 2002 as DOI 10.1099/ ijs.0.02191-0.

Abbreviations: HSP60, $60 \mathrm{KDa}$ heat-shock protein; ITS, internally transcribed spacer; MRS, Man-Rogosa-Sharpe; OTU, operational taxonomic unit; RDP, Ribosomal Database Project.

The GenBank accession numbers for the 16S rRNA gene, ITS and HSP60 sequences of isolate P06 ${ }^{\top}$ are AF404716, AF405360 and AF405395. Accession numbers of other sequences obtained in this study are listed in Table 1. has been based on habitat, DNA-DNA hybridization results and tolerance of temperature, $\mathrm{pH}$ and $\mathrm{NaCl}$ (Garvie, 1974, 1986). However, speciation of Pediococcus isolates has been difficult.

While phenotypic patterns are useful in classifying variable organisms, bacteria often exhibit similar characteristics, making speciation difficult. As protein and nucleic acid sequences allow direct assessment of evolutionary relationships, phylogenetics is increasingly being used to redefine bacterial taxonomy. The most extensive studies regarding the phylogenetics of bacteria are based on the 16S rRNA gene. Using $16 \mathrm{~S}$ rRNA gene sequences, the genus Pediococcus was reported to fall within the Lactobacillus casei branch of the lactic acid bacteria, with Pediococcus dextrinicus as a distantly related species (Collins et al., 1990, 1991; Collins \& Wallbanks, 1992). Within the Pediococcus taxon, Pediococcus damnosus and Pediococcus parvulus formed one cluster, while Pediococcus acidilactici and 
Pediococcus pentosaceus formed a second cluster. Currently, seven Pediococcus species are recognized, including $P$. acidilactici, $P$. damnosus, $P$. dextrinicus, Pediococcus inopinatus, $P$. parvulus, $P$. pentosaceus and Pediococcus urinaeequi. It should be noted that Collins et al. (1990) have suggested that $P$. urinaeequi should be reclassified in the genus Aerococcus; however, no official opinion on this suggestion has been rendered.

Using 16S rRNA gene sequences to infer organismal phylogeny has been criticized, as it assumes that one molecule reflects organismal evolutionary history. Variability in the $16 \mathrm{~S}-23 \mathrm{~S}$ rRNA internally transcribed spacer (ITS) region has also been used for phylogenetic analyses (Frothingham \& Wilson, 1994; Nour, 1998). To study the ITS region, conserved flanking regions of the $16 \mathrm{~S}$ and $23 \mathrm{~S}$ rRNA genes are used as PCR primer-binding sites. Further corroboration of phylogeny can be based on highly conserved proteins that are essential for survival (i.e. have properties of a molecular chronometer; Woese, 1987). One such protein is the $60 \mathrm{kDa}$ heat-shock protein (HSP60), which performs an essential protein-folding function in cells (Gupta et al., 1995; Braig, 1998).

In our examination of the phylogeny of the genus Pediococcus, we used sequence information from three genomic regions, including the 16S rRNA gene, 16S-23S rRNA ITS region and HSP60 gene. We also examined a larger number of Pediococcus isolates than previous studies of this genus. Each of the three phylogenetic trees created have similar topologies. The results are used to redefine the current species designations of Pediococcus isolates and to define a novel Pediococcus species.

\section{METHODS}

Bacteria. Lactobacillus and Pediococcus isolates examined are listed in Table 1. Each isolate was first streaked on Man-Rogosa-Sharpe (MRS) agar and grown at $27^{\circ} \mathrm{C}$. Colony morphology, exopolysaccharide production and Gram-staining properties were determined and five colonies with uniform properties were combined and grown in MRS broth. Substrate fermentation was assessed using the API 50 $\mathrm{CH}$ kit (bioMérieux). Incubation was at $27^{\circ} \mathrm{C}$, with results recorded daily for 7 days to ensure that a minor contaminant was not growing as well. Escherichia coli ATCC 11030 and Staphylococcus aureus ATCC 25923 were propagated at $37{ }^{\circ} \mathrm{C}$ in Oxoid nutrient broth 2 . All bacteria were stored at $-70{ }^{\circ} \mathrm{C}$ in double-strength skim milk.

$\mathbf{G}+\mathbf{C}$ content determination. Cells from $10 \mathrm{ml}$ medium were lysed at $60^{\circ} \mathrm{C}$ for $30 \mathrm{~min}$ in $400 \mu 10 \mathrm{mM}$ Tris/ $\mathrm{HCl}, \mathrm{pH} 8 \cdot 0$, $10 \mathrm{mM}$ EDTA and $0.5 \% \mathrm{SDS}$, to which $6 \mu \mathrm{l}$ proteinase $\mathrm{K}$ $\left(20 \mathrm{mg} \mathrm{ml}^{-1}\right.$ in $10 \mathrm{mM}$ Tris $/ \mathrm{HCl}, \mathrm{pH} 7 \cdot 5$, containing $20 \mathrm{mM}$ $\mathrm{CaCl}_{2}$ and $50 \%$ glycerol) was added. After boiling for $5 \mathrm{~min}$, DNA was isolated using an Epicentre Masterpure DNA extraction kit. Extracted DNA was digested according to the standard method of Mesbah et al. (1989). Nucleoside determination was done with a Waters HPLC System fitted with a Waters C18 column $(5 \mu \mathrm{m}, 300 \AA$, $3.9 \times 150 \mathrm{~mm})$. The column was developed for 3 min with $50 \mathrm{mM}$ potassium phosphate buffer, pH 5.6. Over the next $17 \mathrm{~min}$, methanol content was increased linearly from 0 to $20 \%$. The last 4 min of each run was $20 \%$ methanol in buffer. The column was run at $25^{\circ} \mathrm{C}$ for one analysis, while two analyses were done at $30^{\circ} \mathrm{C}$. As the HPLC conditions do not resolve uracil from $\mathrm{dC}, \mathrm{G}+\mathrm{C}$ content $(\mathrm{mol} \%)$ was calculated as $100 \times[\mathrm{dG}] /$ $([\mathrm{dG}]+[\mathrm{T}])$.

DNA extraction. Bacterial cells from $2 \mathrm{ml}$ overnight culture were collected by centrifugation and resuspended in $200 \mu \mathrm{l}$ of a solution of $5 \mathrm{mg}$ lysozyme $\mathrm{ml}^{-1}$. After $30 \mathrm{~min}$ at room temperature, DNA was extracted using the universal procedure of Golbang et al. (1996). The extracted DNA was allowed to air dry for 5 min before being dissolved in $50 \mu \mathrm{l}$ autoclaved, $0 \cdot 2 \mu \mathrm{m}$-filtered reverse-osmosis deionized water. Samples of each batch of MRS broth were subjected to DNA extraction and PCR amplification to ensure that contamination by unknown microbial contaminants had not occurred.

PCR amplification. Each sample contained $1 \times$ Taq buffer (Invitrogen), $1.5 \mathrm{mM} \mathrm{MgCl}, 0.2 \mathrm{mM}$ of each dNTP, $0.2 \mu \mathrm{M}$ of each primer, $1 \mu \mathrm{l}$ template bacterial DNA and $2.5 \mathrm{U}$ Platinum Taq polymerase (Invitrogen) in $100 \mu \mathrm{l}$ reverseosmosis deionized water. Primers $8 \mathrm{~F}\left(5^{\prime}\right.$-AGAGTTTGATCCTGGCTCAG-3') and 534R (5'-ATTACCGCGGCTGCTGG-3') were used to amplify the first 526 bp of the $16 \mathrm{~S}$ rRNA gene (Relman, 1991; Muyzer et al., 1993). To obtain the whole sequence of the 16S rRNA gene for isolates P03 and P06, primers 515F (5'-TGCCAGCAGCCGCGGTAA$\left.3^{\prime}\right)$ and 1542R (5'-GGCTACCTTGTTACGACTT-3') were used (Weisburg et al., 1989). Primers S2 (5'-TTGTACACACCGCCCGTCA-3') and S7 (5'-GGTACTTAGATGTTTCAGTTC-3') were used to amplify the ITS region (Gürtler \& Stanisich, 1996). The primers used to amplify a portion of the HSP60 gene were H729 [5'-cgccagggttttccagtcacgacGAIIIIGCIGGIGA(T/C)GGIACIACIAC-3'] and H730 [5'agcggatacaattcacacagga $(\mathrm{T} / \mathrm{C})(\mathrm{T} / \mathrm{G}) \mathrm{I}(\mathrm{T} / \mathrm{C})(\mathrm{T} / \mathrm{G})-$ ITCICC(A/G)AAICCIGGIGC(T/C)TT-3'] (Goh et al., 2000). The conserved residues in the HSP60 gene are flanked by M13 sequences M13-40 and M13-48 (lower-case).

With primers $8 \mathrm{~F}$ and $534 \mathrm{R}$, the PCR conditions were one cycle of $5 \mathrm{~min}$ at $95^{\circ} \mathrm{C}, 35$ cycles of $1.25 \mathrm{~min}$ at $94^{\circ} \mathrm{C}, 1 \mathrm{~min}$ at $60{ }^{\circ} \mathrm{C}$ and $1 \mathrm{~min}$ at $72^{\circ} \mathrm{C}$ and one cycle of $10 \mathrm{~min}$ at $72{ }^{\circ} \mathrm{C}$. With primers $515 \mathrm{~F}$ and $1542 \mathrm{R}$, the annealing temperature was reduced to $42{ }^{\circ} \mathrm{C}$. When the ITS region was amplified, the annealing temperature was $55^{\circ} \mathrm{C}$ and last cycle lasted for 8 min (Gürtler \& Stanisich, 1996). For amplification of the HSP60 gene, the first cycle was for $3 \mathrm{~min}, 40$ cycles were used and the annealing temperature was $37^{\circ} \mathrm{C}$ (Goh et al., 1996, 2000).

PCR product purification. PCR amplification of the $16 \mathrm{~S}$ rRNA gene and HSP60 gene segments gave single bands of 526 and $652 \mathrm{bp}$, respectively. The products were purified using a QIAquick Spin PCR purification system (Qiagen). The ITS region PCR resulted in one bright band at $530 \mathrm{bp}$ and two weaker bands, at 650 and $750 \mathrm{bp}$. The latter two bands are of the appropriate sizes for ITS regions containing one and two tRNAs, respectively (Gürtler \& Stanisich, 1996; Nour, 1998). As an ITS region containing no tRNAs would yield a product of approximately $530 \mathrm{bp}$ (Nour, 1998), this band was selected. After the band was excised from the gel, the DNA was purified as described by Zhen \& Swank (1993).

DNA sequencing. PCR products were sequenced using the fluorescence-based dideoxy chain-termination method with a thermocycler model GeneAmp PCR system 9700. A Big Dye Terminator kit was used, with an aliquot of $10 \mu \mathrm{l}$ containing approximately $30 \mathrm{ng}$ PCR product and $3 \cdot 2 \mathrm{pM}$ of 
Table 1. Bacterial isolates used in this study

Culture collections: BSO, Dr B. Kirsop, Institute for Biotechnology, Cambridge, UK; CCC, Coors Brewing Company, Golden, CO, USA; Molson, Molson Breweries of Canada Ltd, Montreal, Quebec, Canada; ATCC, American Type Culture Collection, Manassas, VA, USA; NCIMB, National Collection of Industrial and Marine Bacteria, Aberdeen, UK.

\begin{tabular}{|c|c|c|c|c|c|}
\hline \multirow[t]{2}{*}{ Isolate } & \multirow[t]{2}{*}{ Received as } & \multirow[t]{2}{*}{ Revised nomenclature } & \multicolumn{3}{|c|}{ GenBank accession numbers } \\
\hline & & & 16S rRNA & ITS & HSP60 \\
\hline P01 & Pediococcus sp. BSO 77 & P. acidilactici & AF404711 & AF405355 & AF405390 \\
\hline $\mathrm{P} 02$ & Pediococcus sp. BSO 54 & P. acidilactici & AF404712 & AF405356 & AF405391 \\
\hline P03 & Pediococcus sp. CCC B1208 & P. claussenii sp. nov. & AF404713* & AF405357 & AF405392 \\
\hline P04 & P. damnosus Molson B48 & P. damnosus & AF404714 & AF405358 & AF405393 \\
\hline P05 & P. pentosaceus Molson B49 & P. damnosus & AF404715 & AF405359 & AF405394 \\
\hline $\mathrm{P} 06^{\mathrm{T}} \dagger$ & Pediococcus sp. Molson B71 & $P$. claussenii sp. nov. & AF404716* & AF405360 & AF405395 \\
\hline P07 & Pediococcus sp. Molson B72 & P. acidilactici & AF404717 & AF405361 & AF405396 \\
\hline P08 & Pediococcus sp. Molson B76 & P. damnosus & AF404718 & AF405362 & AF405397 \\
\hline P09 & Pediococcus sp. Molson B77 & P. acidilactici & AF404719 & AF405363 & AF405398 \\
\hline P10 & Pediococcus sp. Molson 77b & P. acidilactici & AF404720 & AF405364 & AF405399 \\
\hline $\mathrm{P} 11^{\mathrm{T}}$ & P. damnosus ATCC $29358^{\mathrm{T}}$ & P. damnosus & AF404721 & AF405365 & AF405400 \\
\hline $\mathrm{P} 13$ & P. damnosus ATCC 25249 & P. damnosus & AF404722 & AF405366 & AF405401 \\
\hline P14 & P. damnosus ATCC 11308 & P. damnosus & AF404723 & AF405367 & AF405402 \\
\hline P15 & P. acidilactici NCIMB 6990 & P. acidilactici & AF404724 & AF405368 & AF405403 \\
\hline $\mathrm{P} 16^{\mathrm{T}}$ & $P$. pentosaceus ATCC $33316^{\mathrm{T}}$ & P. pentosaceus & AF404725 & AF405369 & AF405404 \\
\hline P18 & P. damnosus CCC B1056 & P. claussenii sp. nov. & AF404727 & AF405371 & AF405406 \\
\hline P19 & Tetragenococcus sp. CCC B1098 & P. claussenii sp. nov. & AF404728 & AF405372 & AF405407 \\
\hline $\mathrm{P} 20$ & P. dextrinicus CCC B1099 & P. claussenii sp. nov. & AF404729 & AF405373 & AF405408 \\
\hline $\mathrm{P} 21$ & P. pentosaceus CCC B1100 & P. claussenii sp. nov. & AF404730 & AF405374 & AF405409 \\
\hline $\mathrm{P} 22$ & Pediococcus sp. CCC B1260 & P. claussenii sp. nov. & AF404731 & AF405375 & AF405410 \\
\hline $\mathrm{P} 23$ & P. parvulus Spain $2.6^{a} \ddagger$ & P.parvulus & AF404732 & AF405376 & AF405411 \\
\hline $\mathrm{P} 24$ & P. pentosaceus ATCC 33314 & P.pentosaceus & AF404733 & AF405377 & AF405412 \\
\hline $\mathrm{P} 25$ & P. acidilactici ATCC 12697 & P. acidilactici & AF404734 & AF405378 & AF405413 \\
\hline $\mathrm{P} 27$ & P. acidilactici ATCC 8081 & P. pentosaceus & AF404735 & AF405379 & AF405414 \\
\hline P28 & P. acidilactici ATCC 25740 & P. acidilactici & AF404736 & AF405380 & AF405415 \\
\hline P29 & P. damnosus AТCC 43013 & P. parvulus & AF404737 & AF405381 & AF405416 \\
\hline P31 & P. pentosaceus ATCC 10791 & P.pentosaceus & AF404738 & AF405382 & AF405417 \\
\hline P35 & P. damnosus ATCC 11309 & P.pentosaceus & AF404739 & AF405383 & AF405418 \\
\hline P36 & P. damnosus ATCC 25249 & P. damnosus & AF404740 & AF405384 & AF405419 \\
\hline $\mathrm{P} 37^{\mathrm{T}}$ & P. inopinatus ATCC $49902^{\mathrm{T}}$ & P. inopinatus & AF404741 & AF405385 & AF405420 \\
\hline P38 & P. acidilactici $\mathrm{Pac} 1.0^{b}$ & P. acidilactici & AF404742 & AF405386 & AF405421 \\
\hline $\mathrm{L} 27$ & Lactobacillus casei ATCC $334^{c}$ & L. casei & AF404708 & AF405352 & AF405387 \\
\hline $\mathrm{L} 44^{\mathrm{T}}$ & Lactobacillus brevis ATCC $14869^{\mathrm{T}}$ & L. brevis & AF404709 & AF405353 & AF405388 \\
\hline $\mathrm{L} 71^{\mathrm{T}}$ & Lactobacillus plantarum ATCC $14917^{\mathrm{T}}$ & L. plantarum & AF404710 & AF405354 & AF405389 \\
\hline
\end{tabular}

* Sequence is for the full-length 16S rRNA gene.

$\dagger$ Proposed type strain of P. claussenii sp. nov. (= ATCC BAA-344 $\left.{ }^{\mathrm{T}}=\mathrm{DSM} 14800^{\mathrm{T}}\right)$.

† Strains supplied by: $a$, Dr K. Fernandez, Department of Applied Chemistry, University del Pais Vasco, Gipuzka, Spain; $b$, Dr R. Wheatcroft, Agriculture and Agri-food Canada, Guelph, Ontario, Canada; and $c$, Dr Gregor Reid, Lawson Research Institute, London, Ontario, Canada.

primers in each reaction. After 25 cycles of $96^{\circ} \mathrm{C}$ for $10 \mathrm{~s}$, $50{ }^{\circ} \mathrm{C}$ for $5 \mathrm{~s}$ and $60^{\circ} \mathrm{C}$ for $4 \mathrm{~min}$, sequencing was done with an Applied Biosystems 373 DNA sequencer STRETCH model. Sequencing and PCR primers were the same except for HSP60 DNA, where primers M13-40F and M13-48R were used for sequencing.

Sequence analysis. For the 16S rRNA gene and ITS region, the PCR products for all isolates were sequenced in both directions. The HSP60 sequence data were of sufficiently high quality that, for most isolates, only one direction of sequence was completed. The HSP60 DNA sequence data were translated into amino acid sequence and both the DNA and protein sequence data were examined. Each sequence was queried for homologies with BLAST (Altschul et al., 1990). Sequence results for the $16 \mathrm{~S}$ rRNA gene were also queried against entries in the Ribosomal Database Project (RDP; Maidak et al., 2000) (http//www.cme.msn.edu/ $\mathrm{RDP} / \mathrm{html} /$ index.html).

Phylogenetic analysis. Sequence alignments were created using CLUSTAL x (Thompson et al., 1994) applying default 
parameters. Each alignment was visualized and edited using GeneDoc (Nicholas et al., 1997). Alignments were edited to conform with structural information and inferred locations of variable and conserved regions (Neefs et al., 1993). Phylogenetic trees were constructed using programs from the PHYLIP package (Felsenstein, 1989) including SEQBOOT (1000 replicates), DNADIST (Jukes-Cantor model), PROTDIST (Kimura model), NEIGHBOR (neighbour-joining model) and CONSENSE (outgroup option). Phylogenetic trees were visualized using TreeView (Page, 1996). Reliable nodes were also found with maximum-likelihood, Jin-Nei and Kimura's two-parameter analysis followed by neighbour-joining (Saitou \& Nei, 1987).

\section{RESULTS AND DISCUSSION}

The three genomic regions targeted were successfully amplified and sequenced for all isolates listed in Table 1. Distance matrix-based phylogenetic trees for the 16S rRNA gene, 16S-23S rRNA ITS region and HSP60 gene deduced amino acid sequences are presented in Fig. 1 $(\mathrm{a}-\mathrm{c})$. Similar phylogenetic trees were obtained using maximum-likelihood and parsimony methods (not shown). Also, when the first three variable regions of the $16 \mathrm{~S}$ rRNA gene were examined individually, no significant differences were found compared with the tree in Fig. 1(a) (not shown). In all analyses, three Lactobacillus isolates were included as outgroups and to illustrate the relationship between the genera Lactobacillus and Pediococcus.

The similarity of the trees in Fig. 1 strongly supports the assignment of Pediococcus isolates to one of six phylogenetically based operational taxonomic units (OTUs), which form three groups or clusters. OTU is a generic term (Clewley, 1998) that can mean a group of organisms, a single species, a gene or a region of a gene. For the present paper, an OTU corresponds to a species designation. In our distance-matrix analysis of 16S rRNA gene sequences, distance values $<5 \cdot 0$ were taken to indicate a cluster (i.e. of OTUs), while distances $<1.0$ were taken to indicate an OTU or species [comparable OTUs for the ITS region and HSP60 sequences are respectively given in Fig. 1(b) and (c)]. Each sequence from the 16S rRNA gene was queried against the RDP (Table 2). Complete 16S rRNA gene sequences from two novel isolates included in this study were compared with $16 \mathrm{~S}$ rRNA gene sequences from pediococci already in GenBank and a phylogenetic tree was created (Fig. 2).

Pediococcus cluster 1 consists of a single OTU containing isolates collected by two independent breweries. For each of the phylogenetic trees in Fig. 1, OTU 1 forms a distinct group (with a high bootstrap value at the branch point) containing isolates $\mathrm{P} 03, \mathrm{P} 06^{\mathrm{T}}, \mathrm{P} 18$, P19, P20, P21 and P22. Except for isolates P03 and P21, all of these isolates produce an exopolysaccharide. However, this property can be lost with repeated culturing in broth medium (unpublished results). 16S rRNA gene sequencing of ropy and non-ropy colonies from isolate $\mathrm{P} 06^{\mathrm{T}}$ found no sequence differences, indicating that the ropy property does not affect, nor is affected by, the 16S rRNA gene and its function(s).
A comparison was made of isolates $\mathrm{P} 03$ and $\mathrm{P} 06^{\mathrm{T}}$ with other GenBank entries based on the whole 16S rRNA gene. The phylogenetic tree created (Fig. 2) shows that isolates included in OTU 1 are distant from Pediococcus entries included from GenBank, while still remaining within the Pediococcus $-L$. casei cluster (Collins et al., 1991). Table 2 shows that OTU 1 isolates have low similarity to Pediococcus type isolates based on an RDP similarity search (the closest is $P$. pentosaceus ATCC $33316^{\mathrm{T}}$, with a similarity value of $0 \cdot 74)$. Finally, Table 3 shows that OTU 1 isolates have a distinct substrate fermentation pattern. These results, along with a $\mathrm{G}+\mathrm{C}$ content in the range $34-42 \mathrm{~mol} \%$ expected for pediococci (Garvie, 1986) (Table 4), document the uniqueness of the bacteria in OTU 1 and support our contention that OTU 1 represents a novel Pediococcus species.

Pediococcus cluster 2 contains two OTUs. OTU 2A includes isolates identified as $P$. acidilactici or not yet speciated. The current type isolate of $P$. acidilactici was not included in this study, but the sequence of $P$. acidilactici DSM $20284^{\mathrm{T}}$, available in the RDP, was found to be similar to OTU 2A 16S rRNA sequences (Table 2) and P. acidilactici DSM 20284 ${ }^{\mathrm{T}}$ (accession no. M58833) groups closely with the OTU 2A isolates in the 16S rRNA phylogenetic tree (not shown). OTU 2B includes isolate $\mathrm{P}^{\mathrm{T}} 6^{\mathrm{T}}(=P$. pentosaceus ATCC $33316^{\mathrm{T}}$ ). Isolates $\mathrm{P} 24, \mathrm{P} 27$ and $\mathrm{P} 35$ all have 16S rRNA gene and ITS region sequences similar to those of isolate $\mathrm{P}^{1} 6^{\mathrm{T}}$ (Fig. 1a, b), while isolate P35 is slightly more divergent in the HSP60 protein phylogenetic tree (Fig. 1c). According to the RDP query, OTU 2B 16S rRNA gene sequences are similar to $P$. pentosaceus ATCC $33316^{\mathrm{T}}$. Overall, these data suggest that isolates comprising OTUs $2 \mathrm{~A}$ and $2 \mathrm{~B}$ respectively be assigned to $P$. acidilactici and $P$. pentosaceus.

It is not surprising that isolates comprising OTUs $2 \mathrm{~A}$ and $2 \mathrm{~B}$ are related closely enough to form a taxonomic cluster, as these two species are similar based on morphological, biochemical and physiological properties (Garvie, 1986). Previously, these two species have only been distinguished by DNA-DNA hybridization studies (Back \& Stackebrandt, 1978) and whole 16S rRNA gene sequence data (Collins et al., 1990). Our results show that $P$. acidilactici and $P$. pentosaceus can be separated using the first $526 \mathrm{bp}$ of the $16 \mathrm{~S}$ rRNA gene and using ITS region and HSP60 protein sequence data as well.

The remaining Pediococcus isolates analysed form three OTUs comprising the third taxonomic cluster in our analyses. OTU $3 \mathrm{~A}$ contains isolate $\mathrm{P}^{1} 1^{\mathrm{T}}(=P$. damnosus ATCC $29358^{\mathrm{T}}$ ). This isolate was also most similar to $P$. damnosus in an RDP query (Table 2). Further verification comes from isolates P13 and P36 (both received as $P$. damnosus ATCC 25249), which were obtained in different years from different sources. We found only $1 \mathrm{bp}$ change for the 16S rRNA gene and ITS region and none in the HSP60 protein gene for these two isolates. As such, all OTU 3A isolates should be assigned to $P$. damnosus. 
(a)

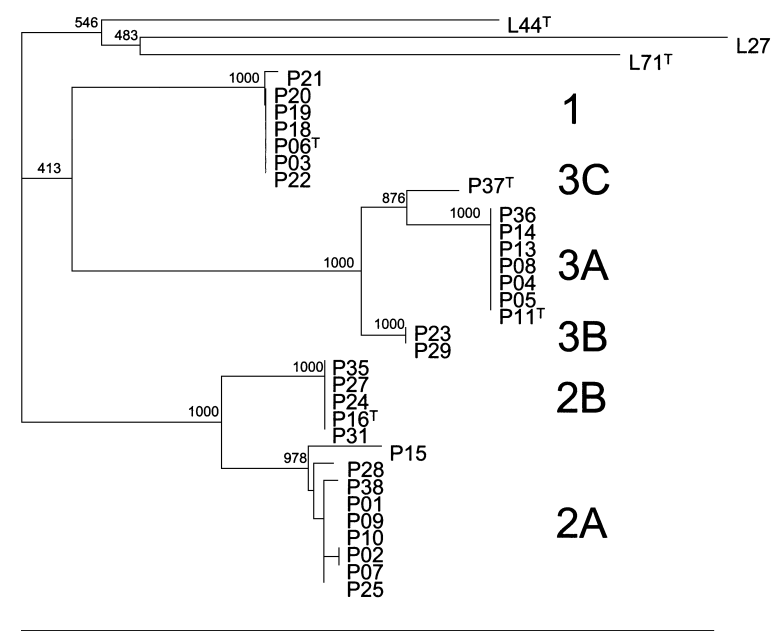

(c)

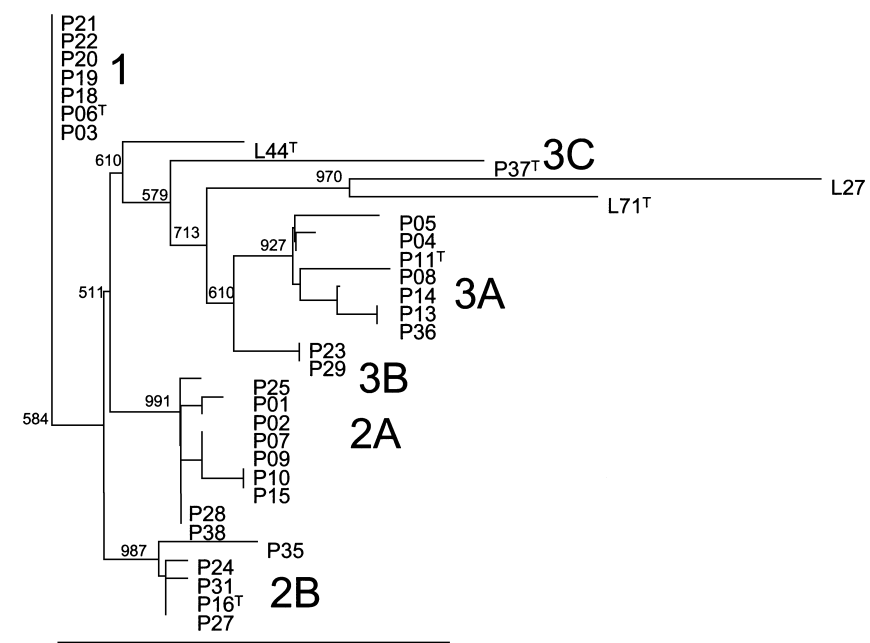

(b)

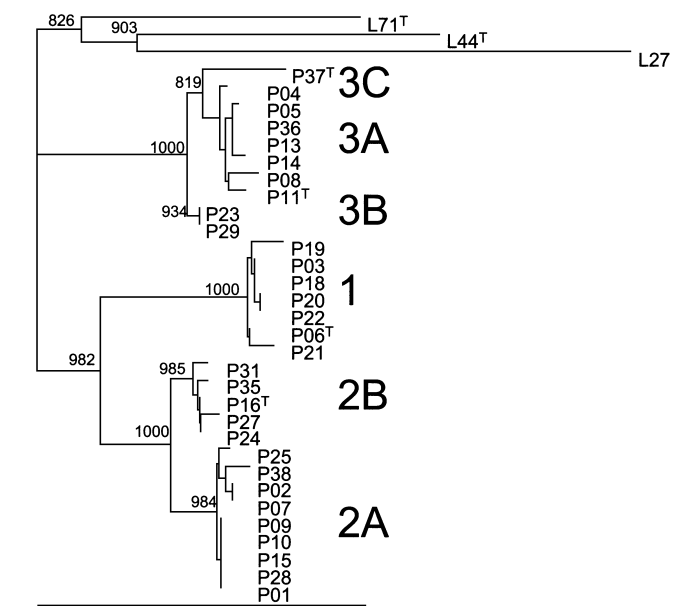

Table 2. RDP similarity query

OTUs corresponds to OTU designations indicated in Fig. 1. Mean scores were calculated based on sequence similarity (Maidak et al., 2000).

\begin{tabular}{|c|c|c|c|}
\hline OTU & Isolates in OTU & $\begin{array}{l}\text { Most similar Pediococcus } \\
\text { sequence in the RDP }\end{array}$ & Mean score (SD) \\
\hline 1 & $\mathrm{P} 03, \mathrm{P} 06^{\mathrm{T}}, \mathrm{P} 18, \mathrm{P} 19, \mathrm{P} 20, \mathrm{P} 21, \mathrm{P} 22$ & P. pentosaceus ATCC $33316^{\mathrm{T}}$ & $0 \cdot 74(0 \cdot 01)$ \\
\hline $2 \mathrm{~A}$ & $\mathrm{P} 01, \mathrm{P} 02, \mathrm{P} 07, \mathrm{P} 09, \mathrm{P} 10, \mathrm{P} 15, \mathrm{P} 25, \mathrm{P} 28, \mathrm{P} 38$ & P. acidilactici DSM $20284^{\mathrm{T}}$ & $0.90(0 \cdot 03)$ \\
\hline $2 \mathrm{~B}$ & $\mathrm{P} 16^{\mathrm{T}}, \mathrm{P} 24, \mathrm{P} 27, \mathrm{P} 31, \mathrm{P} 35$ & P. pentosaceus ATCC $33316^{\mathrm{T}}$ & $0.95(0.03)$ \\
\hline $3 \mathrm{~A}$ & $\mathrm{P} 04, \mathrm{P} 05, \mathrm{P} 08, \mathrm{P} 11^{\mathrm{T}}, \mathrm{P} 13, \mathrm{P} 14, \mathrm{P} 36$ & P. damnosus JCM 5886 & $0.97(0 \cdot 04)$ \\
\hline $3 \mathrm{~B}$ & P23, P29 & P. parvulus JCM $5889^{\mathrm{T}}$ & $0.96(0 \cdot 01)$ \\
\hline $3 \mathrm{C}$ & $\mathrm{P} 37^{\mathrm{T}}$ & P. damnosus JCM 5886 & $0 \cdot 88(0 \cdot 00)$ \\
\hline
\end{tabular}

OTU 3B consists of isolates P23 and P29. These two isolates are most similar to $P$. parvulus $\mathrm{JCM} 5886^{\mathrm{T}}$ according to sequences in the RDP (Table 2). Consequently, we believe that both isolates are $P$. parvulus.
Fig. 1. Unrooted trees showing phylogenetic distances based on (a) DNA sequences from the first three variable regions of the 16S rRNA gene, (b) DNA sequences from the 16S rRNA gene ( $3^{\prime}$ end), the 16S-23S rRNA ITS region and the 235 rRNA gene ( $5^{\prime}$ end) and (c) a 184 amino acid sequence from a portion of the HSP60 gene. In (b), the sequences from the ITS region, which varied in length from 193 to $236 \mathrm{bp}$, were subjected to a BLAST search (http://www.ncbi.nlm.nih.gov/blast) to ensure that Lactobacillus and Pediococcus isolates were involved and that no tRNAs were present in the sequences (Altschul et al., 1990). Bars, 1 nucleotide difference per $100 \mathrm{bp}(\mathrm{a}, \mathrm{b})$ or 1 difference per 100 amino acids (c). Bootstrap values based upon 1000 replicates are included at the major branch points.
Based on 16S rRNA gene data, $P$.damnosus (OTU 3A) and $P$. parvulus (OTU 3B) have previously been acknowledged as closely related (Collins et al., 1990). Although each of the three regions we studied indicates 


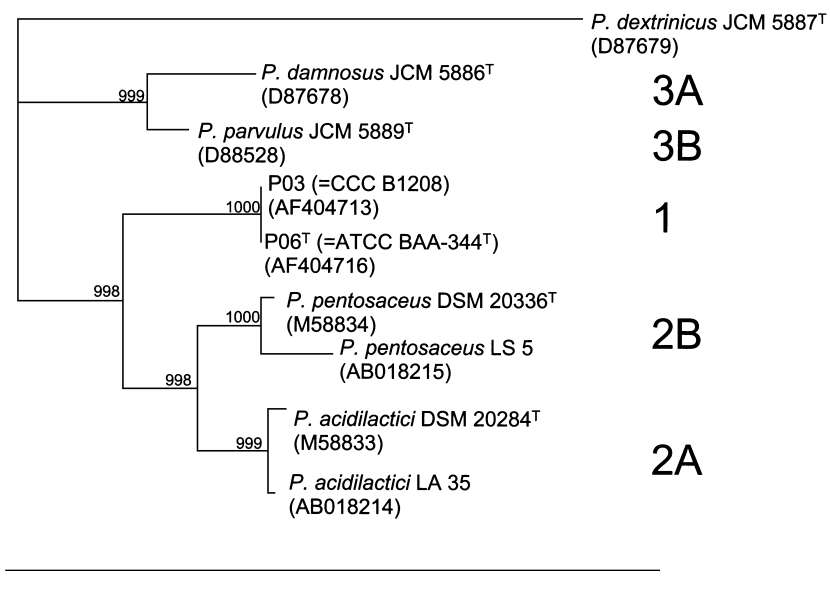

Fig. 2. Unrooted tree showing phylogenetic distances between Pediococcus isolates based on the full-length $16 \mathrm{~S}$ rRNA gene. Data for isolates $\mathrm{P} 03$ and $\mathrm{P}^{\mathrm{T}} \mathrm{6}^{\mathrm{T}}$ are from this study. Other sequences were obtained from GenBank (http://www.ncbi.nlm. nih.gov). Accession numbers are listed in parentheses. Bar, 1 nucleotide difference per $100 \mathrm{bp}$. Bootstrap values based upon 1000 replicates are included at the major branch points.

that OTUs 3A and 3B are distinct, the HSP60 protein sequence had the greatest discriminating power (Fig. 1c).

OTU 3C includes isolate $\mathrm{P} 37^{\mathrm{T}}(=P$. inopinatus ATCC $499902^{\mathrm{T}}$ ). For the $16 \mathrm{~S}$ rRNA gene and ITS region (Fig. 1a, b), isolate $\mathrm{P} 37^{\mathrm{T}}$ exhibited a close genetic relatedness to both $P$. damnosus (OTU 3A) and $P$. parvulus (OTU $3 \mathrm{~B})$, although more divergence was found when the

\section{Table 4. DNA G $+C$ contents}

Values are given in $\mathrm{mol} \%$.

\begin{tabular}{|ll|}
\hline Isolate & Mean \pm SD (n) \\
\hline P. claussenii $\mathrm{P}^{2} 6^{\mathrm{T}}$ (non-exopolysaccharide) & $40 \cdot 2 \pm 0 \cdot 2(3)$ \\
P. claussenii $\mathrm{P}^{\mathrm{T}}$ (exopolysaccharide) & $41 \cdot 1 \pm 0 \cdot 6(3)$ \\
P. damnosus $\mathrm{P} 11^{\mathrm{T}}$ & $42 \cdot 4 \pm 0 \cdot 4(3)$ \\
E. coli ATCC 11030 & $51 \cdot 7 \pm 1 \cdot 0(2)$ \\
S. aureus ATCC 25923 & $35 \cdot 9 \pm 0 \cdot 6(2)$ \\
Salmon-sperm DNA & $46 \cdot 5 \pm 0 \cdot 7(2)$ \\
\hline
\end{tabular}

HSP60 gene sequence was analysed (Fig. 1c). Genome DNA-DNA hybridization studies suggest a close relationship between $P$. inopinatus and $P$. damnosus (Back \& Stackebrandt, 1978). Also, although $P$. inopinatus and $P$. parvulus are similar on the basis of their growth habitats, these species have been separated based on electrophoretic patterns of their lactose dehydrogenases (Back \& Stackebrandt, 1978). Previous phylogenetic studies have not included any $P$. inopinatus DNA sequences and rRNA gene sequences are unavailable in GenBank. Nonetheless, our data show that isolate $\mathrm{P} 37^{\mathrm{T}}$ is distant from the other cluster 3 OTUs, indicating that it represents an independent species, i.e. P. inopinatus.

We originally expected all of the currently accepted Pediococcus species, including $P$. dextrinicus, to be represented by the bacterial isolates analysed here. This expectation was based on isolate $\mathrm{P} 20$ coming to us

Table 3. API $50 \mathrm{CH}$ substrate utilization by $P$. claussenii sp. nov.

Maximal changes were recorded on day 2 for non-ropy isolates and on day 3 for ropy isolates. $N$-Acetylglucosamine, amygdalin, cellobiose, aesculin, D-fructose, $\beta$-gentiobiose, D-glucose, D-mannose and trehalose gave positive results for all of the pediococcus isolates examined. Negative fermentation results for all isolates were obtained with adonitol, starch, D- and L-arabitol, Darabinose, dulcitol, erythritol, D-fucose, gluconate, 2- and 5-ketogluconate, methyl $\alpha$-D-glucoside, glycerol, glycogen, inositol, inulin, D-lyxose, methyl $\alpha$-D-mannoside, melibiose, melezitose, rhamnose, sorbitol, L-sorbose, D-turanose, L-xylose, methyl $\beta$ xyloside and xylitol. Both ropy and non-ropy strains of $P$. claussenii isolates $\mathrm{P} 06^{\mathrm{T}}, \mathrm{P} 18, \mathrm{P} 19, \mathrm{P} 20$ and $\mathrm{P} 22$ were examined and the fermentation results were the same. P. claussenii isolates P03 and P21 were also examined.

\begin{tabular}{|c|c|c|c|c|}
\hline Substrate & P. claussenii (7 isolates) & P. damnosus $\mathrm{P} 11^{\mathrm{T}}$ & P. acidilactici P15 & P. pentosaceus $\mathrm{P} 16^{\mathrm{T}}$ \\
\hline L-Arabinose & - & - & + & + \\
\hline Arbutin & + & + & - & + \\
\hline Galactose & - & + & + & + \\
\hline Lactose & - & - & - & + \\
\hline Maltose & $+^{*}$ & + & - & + \\
\hline Mannitol & $+^{*}$ & - & - & - \\
\hline D-Raffinose & - & - & - & + \\
\hline Ribose & + & - & + & + \\
\hline Sucrose & - & - & - & + \\
\hline Salicin & + & + & - & + \\
\hline D-Tagatose & - & - & + & + \\
\hline D-Xylose & - & - & + & + \\
\hline
\end{tabular}

* Not fermented by P. claussenii P03. 
identified as $P$. dextrinicus. However, in all three phylogenetic trees, this isolate fell into OTU 1, namely Pediococcus claussenii sp. nov. The inclusion of $P$. dextrinicus ATCC $33087^{\mathrm{T}}$ in the phylogenetic tree created with full-length $16 \mathrm{~S}$ rRNA gene sequence data (Fig. 2) reveals that $P$. dextrinicus is an outlier compared with other pediococci. This fits with the RDP, which has $P$. dextrinicus within the Lactobacillus perolens subgroup, not the Pediococcus subgroup, of the Lactobacillus division. Results obtained by Collins et al. (1990) and Stiles \& Holzapfel (1997) also group $P$. dextrinicus within the lactobacilli. These findings appear to support the reclassification of $P$. dextrinicus within Lactobacillus. However, to date, no formal request has been made for this change.

The phylogenetic analyses presented here establish that the 16S rRNA gene, ITS region and HSP60 gene sequences are all useful in delineating species of the genus Pediococcus. We believe that the total congruence of the three phylogenetic trees allows taxonomic assignments to be made with much more conviction than if based on just one DNA sequence (e.g. the 16S rRNA gene). More specifically, the consistency of OTU placement for the 31 isolates included in this study strongly supports the conclusion that many Pediococcus species designations should be revised (as indicated in Table 1) and the conclusion that OTU 1 does indeed represent a novel Pediococcus species, for which the name Pediococcus claussenii sp. nov. is proposed.

\section{Description of Pediococcus claussenii sp. nov.}

Pediococcus claussenii (claus'sen.i.i. N.L. n. claussenii in honour of N. H. Claussen, who first used the genus name Pediococcus in 1903 for isolates of beer-spoilage bacteria).

The proposal of the name Pediococcus claussenii avoids any confusion that may have arisen with the revival of obsolete names such as 'Pediococcus cerevisiae', 'Pediococcus flavus', 'Pediococcus gadidarum', 'Pediococcus odoris' or 'Pediococcus tetrus'.

Cells are cocci, $0 \cdot 6-1 \mu \mathrm{m}$ in diameter. They are Grampositive, non-motile, do not form spores and occur singly, in pairs or in tetrads. Colonies are white, convex, smooth, circular and opaque if exopolysaccharide is not present. When exopolysaccharide is produced, colonies are grey, convex, circular, smooth, glistening, opaque and sticky. In broth, growth causes turbidity. The broth clears in a few days if the cells are non-ropy. For ropy cells, the turbidity remains much longer, as the cells settle slowly. Acid is produced from $\mathrm{N}$-acetylglucosamine, amygdalin, arbutin, cellobiose, aesculin, D-fructose, $\beta$-gentiobiose, D-glucose, D-mannose, ribose, salicin and trehalose. Most strains ferment mannitol and maltose. Acid is not produced from adonitol, starch, L-arabinose, D- or L-arabitol, Darabinose, dulcitol, erythritol, D-fucose, galactose, gluconate, 2 - or 5-ketogluconate, methyl $\alpha$-D-gluco- side, glycerol, glycogen, inositol, inulin, lactose, Dxylose, methyl $\alpha$-D-mannoside, melibiose, melezitose, D-raffinose, rhamnose, sucrose, sorbitol, L-sorbose, Dtagatose, D-turanose, D- or L-xylose, methyl $\beta$-xyloside or xylitol. Fermentation patterns for ropy and nonropy variants are identical.

All isolates reported here were brewery isolates. The $\mathrm{G}+\mathrm{C}$ content is $40 \cdot 0-41 \cdot 7 \mathrm{~mol} \%$. The type strain is isolate $\mathrm{P}^{2} 6^{\mathrm{T}}\left(=\mathrm{ATCC}\right.$ BAA- $\left.344^{\mathrm{T}}=\mathrm{DSM} 14800^{\mathrm{T}}\right)$. The description of the type isolate corresponds to that of the species. This isolate can be obtained in an exopolysaccharide-producing form; however, this characteristic can be lost upon repeated broth culture. Colonies showing a ropy phenotype should be used frequently to initiate broth cultures to maintain the ropy phenotype in liquid medium.

\section{ACKNOWLEDGEMENTS}

This research was supported by Coors Brewing Company, Golden, Colorado. C.M.D. was awarded an Arthur Smyth Scholarship from the College of Medicine, University of Saskatchewan. DNA sequencing was done by Dr Inge Roewer, Plant Biotechnology Institute, National Research Council, Saskatoon, Saskatchewan.

\section{REFERENCES}

Altschul, S. F., Gish, W., Miller, W., Myers, E. W. \& Lipman, D. J. (1990). Basic local alignment search tool. J Mol Biol 215, 403-410.

Back, W. \& Stackebrandt, E. (1978). DNS/DNS homogie studien innerhalb der Gattung Pediococcus. Arch Microbiol 118, 79-85.

Braig, K. (1998). Chaperonins. Curr Opin Struct Biol 8, 159-165.

Clewley, J. P. (1998). A user's guide to producing and interpreting tree diagrams in taxonomy and phylogenetics. Part I. Introduction and naming of parts. Commun Dis Public Health 1, 64-66.

Collins, M. D. \& Wallbanks, S. (1992). Comparative sequence analyses of the 16S rRNA genes of Lactobacillus minutus, Lactobacillus rimae and Streptococcus parvulus: proposal for the creation of a new genus Atopobium. FEMS Microbiol Lett 95, 235-240.

Collins, M. D., Williams, A. M. \& Wallbanks, S. (1990). The phylogeny of Aerococcus and Pediococcus as determined by 16S rRNA sequence analysis: description of Tetragenococcus gen. nov. FEMS Microbiol Lett 70, 255-262.

Collins, M. D., Rodriguez, U., Ash, C., Aguirre, M., Farrow, J. A. E., Martinez-Murcia, A., Philips, B. A., Williams, A. M. \& Wallbanks, S. (1991). Phylogenetic analysis of the genus Lactobacillus and related lactic acid bacteria as determined by reverse transcriptase sequencing of 16S rRNA. FEMS Microbiol Lett 77, 5-12.

Felsenstein, J. (1989). PHYLIP - Phylogeny Inference Package (version 3.2). Cladistics 5, 164-166.

Frothingham, R. \& Wilson, K. H. (1994). Molecular phylogeny of the Mycobacterium avium complex demonstrates clinically meaningful divisions. J Infect Dis 169, 305-312.

Garvie, E. I. (1974). Nomenclatural problems of the pediococci. Request for an Opinion. Int J Syst Bacteriol 24, 301-306.

Garvie, E. I. (1986). Genus Pediococcus Claussen 1903, 68 ${ }^{\mathrm{AL}}$. In Bergey's Manual of Systematic Bacteriology, vol. 2, pp. 1075-1079. Edited by P. H. A. Sneath, N. S. Mair, M. E. Sharpe \& J. G. Holt. Baltimore: Williams \& Wilkins.

Goh, S. H., Potter, S., Wood, J. O., Hemmingsen, S. M., Reynolds, R. P. \& Chow, A. W. (1996). HSP60 gene sequences as universal targets for microbial species identification: studies with coagulase-negative staphylococci. J Clin Microbiol 34, 818-823. 
Goh, S. H., Facklam, R. R., Chang, M. \& 8 other authors (2000). Identification of Enterococcus species and phenotypically similar Lactococcus and Vagococcus species by reverse checkerboard hybridization to chaperonin 60 gene sequences. J Clin Microbiol 38, 3953-3959.

Golbang, N., Burnie, J. P., Klapper, P. E., Bostock, A. \& Williamson, P. (1996). Sensitive and universal method for microbial DNA extraction from blood products. J Clin Pathol 49, 861-863.

Gupta, R. S. (1995). Evolution of the chaperonin families (Hsp60, Hsp10 and Tcp-1) of proteins and the origin of eukaryotic cells. Mol Microbiol 15, 1-11.

Gürtler, V. \& Stanisich, V. A. (1996). New approaches to typing and identification of bacteria using the $16 \mathrm{~S}-23 \mathrm{~S}$ rRNA spacer region. Microbiology 142, 3-16.

Maidak, B. L., Cole, J. R., Lilburn, T. G. \& 9 other authors (2000). The RDP (Ribosomal Database Project) continues. Nucleic Acids Res 28, 173-174.

Mesbah, M., Premachandran, U. \& Whitman, W. B. (1989). Precise measurement of the $\mathrm{G}+\mathrm{C}$ content of deoxyribonucleic acid by highperformance liquid chromatography. Int J Syst Bacteriol 39, 159-167.

Muyzer, G., de Waal, E. C. \& Uitterlinden, A. G. (1993). Profiling of complex microbial populations by denaturing gradient gel electrophoresis analysis of polymerase chain reaction-amplified genes coding for 16S rRNA. Appl Environ Microbiol 59, 695-700.

Neefs, J. M., Van de Peer, Y., De Rijk, P., Chapelle, S. \& De Wachter, R. (1993). Compilation of small ribosomal subunit RNA structures. Nucleic Acids Res 21, 3025-3049.
Nicholas, K. B., Nicholas, H. B. J. \& Deerfield, D. W. I. (1997). GeneDoc: analysis and visualization of genetic variation. EMB News 4 , 14.

Nour, M. (1998). 16S-23S and 23S-5S intergenic spacer regions of lactobacilli: nucleotide sequence, secondary structure and comparative analysis. Res Microbiol 149, 433-448.

Page, R. D. M. (1996). TreeView: an application to display phylogenetic trees on personal computers. Comput Appl Biosci 12, 357-358.

Relman, D. A. (1991). Universal bacterial 16D rDNA amplification and sequencing. In Diagnostic Molecular Microbiology: Principles and Applications, pp. 489-495. Edited by D. H. Persing, T. F. Smith, F. C. Tenover \& T. J. White. Washington, DC: American Society for Microbiology.

Saitou, N. \& Nei, M. (1987). The neighbor-joining method: a new method for reconstructing phylogenetic trees. Mol Biol Evol 4, 406-425.

Stiles, M. E. \& Holzapfel, W. H. (1997). Lactic acid bacteria of foods and their current taxonomy. Int J Food Microbiol 36, 1-29.

Thompson, J. D., Higgins, D. G. \& Gibson, T. J. (1994). CluSTAL W: improving the sensitivity of progressive multiple sequence alignment through sequence weighting, position-specific gap penalties and weight matrix choice. Nucleic Acids Res 22, 4673-4680.

Weisburg, W. G., Tully, J. G., Rose, D. L. \& 9 other authors (1989). A phylogenetic analysis of the mycoplasmas: basis for their classification. J Bacteriol 171, 6455-6467.

Woese, C. R. (1987). Bacterial evolution. Microbiol Rev 51, 221-271. Zhen, L. \& Swank, R. T. (1993). A simple and high yield method for recovering DNA from agarose gels. Biotechniques 14, 894-898. 